\title{
Investigation of Synthesis and some Properties of the Copper Complexes Containing Imidazole Ligand
}

\author{
Emin Erdem, ${ }^{1}$ Mehri Akarsu, ${ }^{1}$ Rafet Kılınçarslan, ${ }^{1,}{ }^{*}$ İsmail Kayağil, ${ }^{2}$ İzzet Kara, ${ }^{3}$ Sevil Söyleyici ${ }^{1}$
}

\footnotetext{
1 Department of Chemistry, Faculty of Science\&Arts, Pamukkale University, 20017, Denizli-Turkey

2 Department of Chemistry, Faculty of Science\&Arts M. Akif Ersoy University, 15030, Burdur-Turkey

3 Department of Science Education, Pamukkale University, 20070, Denizli-Turkey

* Corresponding author's e-mail address: rkilincarslan@pau.edu.tr
}

RECEIVED: January 6, 2016 * REVISED: February 24, 2016 * ACCEPTED: February 25, 2016

Abstract: The copper(II) complexes bearing tetrasubstituted imidazole derivatives containing oxygen donor as ligands ( $\mathrm{L}_{1-6}$ ) were synthesized and characterized by spectroscopic methods, magnetic measurements, elemental and thermogravimetric analyses. The fluorescence efficiency of the ligands ( $\left.\mathrm{L}_{1-6}\right)$ and their copper(II) complexes were investigated at r.t. in DMF solution. Theoretical calculations were performed for the copper(II) complex of $\mathrm{L}_{4}$ ligand, in this study. The molecular geometry, bond lengths, bond angles and vibrational wave numbers were calculated by using ab initio calculations based on the Hartree-Fock $\{\mathrm{HF} / 6-31 \mathrm{G}(\mathrm{d})\}$ and the density functional theory $\{\mathrm{B} 3 \mathrm{LYP} / 6-31 \mathrm{G}(\mathrm{d})\}$ in the ground state.

Keywords: copper(II), fluorescence, tetrasubstituted imidazole, Hartree-Fock.

\section{INTRODUCTION}

C OPPER(II) complexes have been studied because of their coordination geometries, exquisite colours, technical application dependent molecular structures, spectroscopic properties and fluorescent chemosensors applications. ${ }^{[1-3]}$ Fluorescent chemosensors for the detection of biologically relevant metal ions have been widely exploited in the chemistry. Among the various transition metal ions, the copper ion draws significant attention due to its vital role in biological systems. On the other hand, the copper ion causes significant environ-mental pollution and also serves as a catalytic cofactor for a variety of metalloenzymes. ${ }^{[4-6]}$ Methods for the detection of copper have got important implications in the areas of environmental and biological analyses. ${ }^{[7]}$ As an important member of the five-membered ring hetero-cycles, the imidazole moiety is present in a wide range of naturally occurring molecules. Imidazoles also have an ability to behave as ligands in metalloenzymes and non-natural metal complexes. ${ }^{[8-11]}$ The preparation of pho-tochromic systems that assimilate several switchable functions into a particular molecule has garnered much attention because of the potential applications of such systems. ${ }^{\left[{ }^{[-12]}\right.}$ Photochromic fluorescent compounds are one of these systems that can reversibly convert fluorescence intensity via a photochromic reaction and can be used for optical memory media as well as for fluorescent probes. ${ }^{[13,14]}$ In addition of their fluorescent properties, imidazole derivatives have numerous pharmacological properties and participate in several vital biochemical processes. ${ }^{[15,16]}$ Absorbance and fluo-rescence studies utilize low cost equipment which is easily affordable by many laboratories, and fluorimetric techniques are more attractive because of their high sensitivity and reliability.

We have described that some 2,3,6,8-tetraaryl-imidazo[1,2a]pyrazine derivatives which show notable anticancer activities were synthesized by reacting 1-(2-aryl-2oxoethyl)-2-aryloyl-4,5-diarylimidazole and 2-bromoa-cetophenone derivatives with ammonium acetate in acetic acid by using the method that was previously developed. ${ }^{[17,18]}$ In the course of our studies involving the use of functionalized 1,2,4,5-tetrasubstituted imidazole ligands $\left(\mathrm{L}_{1-6}\right)$, we report selectivity towards copper ions in solution and also their copper(II) complexes, $\left[\mathrm{Cu}\left(\mathrm{L}_{1-6}\right)_{2}\left(\mathrm{OH}_{2}\right)_{2}\right](\mathrm{OAc})_{2}$ were synthesized and characterized. 


\section{EXPERIMENTAL}

\section{General Considerations}

FTIR-ATR spectra ( $\mathrm{KBr}$ pellets): Mattson 1000 FTIR Spectrometer; UV-VIS absorption spectra: Shimadzu UV-1601 Spectrometer; ${ }^{1} \mathrm{H}$ NMR spectra: Varian spectrometer operated at $400 \mathrm{MHz}$; Maldi-MS spectra: Bruker Microflex LT MALDI-TOF MS; Elemental C, $\mathrm{H}, \mathrm{N}$ analysis: Perkin Elmer 240B analyzer. Fluorescence Intensity: Perkin Elmer LS55. Chemicals were obtained from Sigma-Aldrich and used without further purification. Reactions were all monitored by TLC, performed on silica gel plates 60 F254 (Merck). Visualization on TLC was achieved by UV light. Melting points of all the compounds were determined on electrothermal apparatus. TG and DTA curves were obtained by using DTG-60H Shimadzu DTA-TG analyzer. The measurements were carried out in flowing nitrogen atmosphere within the temperature range of $20-1000^{\circ} \mathrm{C}$ in a platinum crucible. The heating rate was $10^{\circ} \mathrm{C} / \mathrm{min}$ and the sample masses were in the range of $2-3 \mathrm{mg}$. Highly sintered $\alpha-\mathrm{Al}_{2} \mathrm{O}_{3}$ was used as the reference material. Magnetic susceptibilities were determined on a Sherwood Scientific Magnetic Susceptibility Balance (Model MK1) at room temperature $\left(20^{\circ} \mathrm{C}\right)$ using $\mathrm{Hg}\left[\mathrm{Co}(\mathrm{SCN})_{4}\right]$ as a calibrant; diamagnetic corrections were calculated from Pascal's constants. ${ }^{[19]}$ All the calculations were performed by using Gaussian 09.A1 program on ULAKBIM clusters and Gauss View 5.0.8 was used for visualization of the structure and simulated vibrational spectra. [20-23]

\section{Preparation of ligands}

The preparation of functionalized 1-(2-aryl-2-oxoethyl)-2aryloyl-4,5-diarylimidazole ligands $\left(\mathbf{L}_{1-6}\right)$ started from diarylimidazole. The synthetic route for the ligands is shown in Figure 1. These ligands were synthesized according to the methods reported in the literature; ${ }^{[17,18]}$ in a three-step process in which 4,5-diarylimidazoles ( $\left.\mathbf{I}_{\mathbf{a}-\mathrm{c}}\right)$ were first synthesized by benzoyls were taken as starting materials and reacted with urotropine and ammonium acetate in acetic acid. In the second step, 4,5-diarylimidazole derivatives ( $\left.\mathbf{I}_{\text {a-c }}\right)$ were reacted with suitable benzoylchlorides in pyridine and<smiles>O=C(C(=O)c1ccc(Br)cc1)c1ccc(Br)cc1</smiles><smiles>Oc1ccc(-c2nc[nH]c2-c2ccc(Br)cc2)cc1</smiles><smiles>[R]C(C)COCl</smiles>

$I_{a-c}$<smiles>C1N2CN3CN1CN(C2)C3</smiles>

$I_{a-z}$<smiles>O=C(CBr)c1ccc(C(=O)c2nc(-c3ccc(F)cc3)c(-c3ccc(F)cc3)n2CC(=O)c2ccc(F)cc2)cc1</smiles>

Figure 1. Synthesis of 1-(2-aryl-2-oxoethyl)-2-aryloyl-4,5-diarylimidazole ligands ( $\left.L_{1-6}\right)$. 


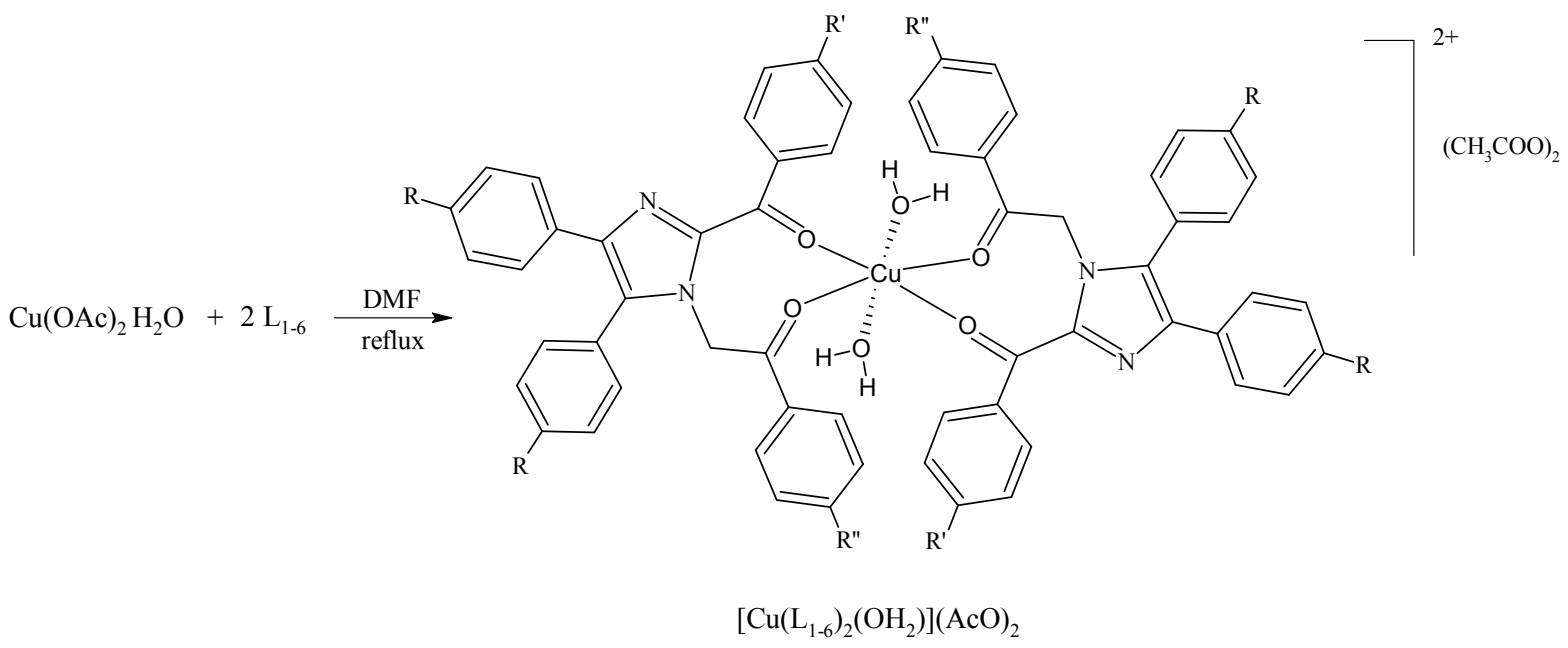

Figure 2. Proposed structure of the copper (II) complexes.

triethylamine to give 2-aryloyl-4,5-diarylimidazoles derivatives $\left(\mathrm{II}_{\mathrm{a}-\mathrm{I}}\right)$. In the third step, 2-aryloyl-4,5-diarylimidazoles derivatives $\left(\mathrm{II}_{\mathrm{a}-\mathrm{I}}\right)$ were then reacted with suitable 2bromoacetophenones to give 1-(2-aryl-2-oxoethyl)-2-aryloyl-4,5-diarylimidazoles $\left(\mathbf{L}_{\mathbf{1}-6}\right)$.

\section{Preparation of copper(II) complexes}

The copper(II) complexes, $\left[\mathrm{Cu}\left(\mathrm{L}_{1-6}\right)_{2}\left(\mathrm{OH}_{2}\right)_{2}\right](\mathrm{OAc})_{2}$ can be prepared in analogy to published procedures according to a slightly modified procedure from the literature methods ${ }^{[24]}$ depicted in Figure 2. All the complexes were synthesized by addition of $\mathrm{Cu}(\mathrm{OAc})_{2} \mathrm{H}_{2} \mathrm{O}(0.5 \mathrm{mmol}$, in $15 \mathrm{~mL}$ of hot DMF) to a solution of the 1,2,4,5-tetrasubstituted imidazole derivatives $\left(\mathbf{L}_{1-6}\right)$ as ligand $(1.0 \mathrm{mmol}$ in $20 \mathrm{~mL}$ DMF). The resulting solutions were refluxed for $2 \mathrm{~h}$. The volume of the obtained solution was then reduced to one-half by evaporation. The mixture was poured into cold water and then kept for $30 \mathrm{~min}$ in an ice bath. The crude precipitate was isolated by filtration, washed several times with water, ethanol and then dried under vacuum. Purity was examined in a mixture of $5 \%$ water/DMSO by TLC with Kieselgel $60 \mathrm{HF}_{254}$.

\section{$\left[\mathrm{Cu}\left(\mathrm{L}_{1}\right)_{2}\left(\mathrm{H}_{2} \mathrm{O}\right)_{2}\right](\mathrm{OAc})_{2}$}

Color: Brown. Yield: 72 \%. d.p. $232{ }^{\circ} \mathrm{C}$. Anal. Calcd. for $\mathrm{C}_{68} \mathrm{H}_{62} \mathrm{~N}_{4} \mathrm{O}_{10} \mathrm{Cu}: \mathrm{C}, 70.48 ; \mathrm{H}, 5.39 ; \mathrm{N}, 4.83$. Found: $\mathrm{C}, 70.53 ; \mathrm{H}$, 5.42 ; N, 4.87 \%. IR (KBR) $\tilde{v} / \mathrm{cm}^{-1}: 1700,1635,1442,1598-$ $1457,716,426 . \mathrm{MS}(\mathrm{m} / \mathrm{z}): 1160\left(\mathrm{M}^{+1}, 48 \%\right), 1161\left(\mathrm{M}^{+2}, 36 \%\right)$.

\section{$\left[\mathrm{Cu}\left(\mathrm{L}_{2}\right)_{2}\left(\mathrm{H}_{2} \mathrm{O}\right)_{2}\right](\mathrm{OAC})_{2}$}

Color: Brown. Yield: 68 \%. d.p. $230{ }^{\circ} \mathrm{C}$. Anal. Calcd. for $\mathrm{C}_{68} \mathrm{H}_{60} \mathrm{~N}_{4} \mathrm{O}_{10} \mathrm{Cl}_{2} \mathrm{Cu}: \mathrm{C}, 66.53 ; \mathrm{H}, 4.93 ; \mathrm{N}, 4.56$. Found $\mathrm{C}, 66.83$; $\mathrm{H}, 4.91 ; \mathrm{N}, 4.58 \%$. MS (m/z): $1129\left(\mathrm{M}^{+1}, 52 \%\right), 1130\left(\mathrm{M}^{+2}\right.$, $40 \%)$.

\section{$\left[\mathrm{Cu}\left(\mathrm{L}_{3}\right)_{2}\left(\mathrm{H}_{2} \mathrm{O}\right)_{2}\right](\mathrm{OAC})_{2}$}

Color: Brown. Yield: 70 \%. d.p. $193{ }^{\circ} \mathrm{C}$. Anal. Calcd. for $\mathrm{C}_{68} \mathrm{H}_{58} \mathrm{~N}_{4} \mathrm{O}_{10} \mathrm{Cl}_{4} \mathrm{Cu}: \mathrm{C}, 62.99 ; \mathrm{H}, 4.51 ; \mathrm{N}, 4.32$. Found: $\mathrm{C}$, 63.18; H, 4.49; N, $4.33 \%$. MS (m/z): $1297\left(\mathrm{M}^{+1}, 44 \%\right)$.

\section{$\left[\mathrm{Cu}\left(\mathrm{L}_{4}\right)_{2}\left(\mathrm{H}_{2} \mathrm{O}\right)_{2}\right](\mathrm{OAC})_{2}$}

Color: Brown. Yield: 66 \%. d.p. $198{ }^{\circ} \mathrm{C}$. Anal. Calcd. for $\mathrm{C}_{68} \mathrm{H}_{60} \mathrm{~N}_{4} \mathrm{O}_{14} \mathrm{Cl}_{2} \mathrm{Cu}$ : C, 63.23; $\mathrm{H}, 4.68 ; \mathrm{N}, 4.34$. Found: $\mathrm{C}$, 63.38; $\mathrm{H}, 4.70 ; \mathrm{N}, 4.36 \%$. MS (m/z): $1292\left(\mathrm{M}^{+1}, 40 \%\right)$.

\section{$\left[\mathrm{Cu}\left(\mathrm{L}_{5}\right)_{2}\left(\mathrm{H}_{2} \mathrm{O}\right)_{2}\right](\mathrm{OAc})_{2}$}

Color: Brown. Yield: 72 \%. d.p. $196{ }^{\circ} \mathrm{C}$. Anal. Calcd. For $\mathrm{C}_{68} \mathrm{H}_{58} \mathrm{~N}_{4} \mathrm{O}_{14} \mathrm{Cl}_{4} \mathrm{Cu}: \mathrm{C}, 60.03 ; \mathrm{H}, 4.30 ; \mathrm{N}, 4.12$. Found: $\mathrm{C}$, $60.42 ; \mathrm{H}, 4.27 ; \mathrm{N}, 4.17 \%$. MS (m/z): $1361\left(\mathrm{M}^{+1}, 48 \%\right), 1362$ $\left(\mathrm{M}^{+2}, 36 \%\right)$.

\section{$\left[\mathrm{Cu}\left(\mathrm{L}_{6}\right)_{2}\left(\mathrm{H}_{2} \mathrm{O}\right)_{2}\right](\mathrm{OAc})_{2}$}

Color: Brown. Yield: $68 \%$. d.p. $208-209^{\circ} \mathrm{C}$. Anal. Calcd. for $\mathrm{C}_{68} \mathrm{H}_{54} \mathrm{~N}_{4} \mathrm{O}_{12} \mathrm{Cl}_{4} \mathrm{Cu}$ : C, 60.95; $\mathrm{H}, 4.19 ; \mathrm{N}, 4.31$; found C, 61.09; $H, 4.22 ; \mathrm{N}, 4.28 \%$. MS (m/z): $1301\left(\mathrm{M}^{+1}, 42 \%\right)$.

\section{RESULTS AND DISCUSSION}

\section{Synthesis}

The preparation of functionalized 1-(2-aryl-2-oxoethyl)-2aryloyl-4,5-diarylimidazoles $\left(\mathbf{L}_{1-6}\right)$ containing dissymmetrical carbonyl groups were synthesized according to the methods previously known as shown Figure 1.

According to Figure 2, the copper(II) complexes derived from 1,2,4,5-tetrasubstituted imidazoles were obtained upon reacting between copper ions and ligands at 1:2 molar ratio by refluxing in DMF for $2 \mathrm{~h}$. The ligands, on 
Table 1. Some analytical data and physical properties of the ligands and their complexes

\begin{tabular}{ccccccc}
\hline \multirow{2}{*}{ Compounds } & \multirow{2}{*}{ Empirical Formula } & M.p. $/{ }^{\circ} \mathrm{C}$ & Yield / \% & \multicolumn{3}{c}{ Found (Calcd.) / \% } \\
\hline $\mathrm{L}_{1}$ & $\mathrm{C}_{32} \mathrm{H}_{26} \mathrm{~N}_{2} \mathrm{O}_{2}$ & 176 & 88 & $55.92(55.97)$ & $3.84(3.82)$ & $12.20(12.24)$ \\
$\mathrm{L}_{2}$ & $\mathrm{C}_{32} \mathrm{H}_{25} \mathrm{ClN}_{2} \mathrm{O}_{2}$ & 223 & 82 & $58.22(58.21)$ & $4.59(4.61)$ & $11.32(11.31)$ \\
$\mathrm{L}_{3}$ & $\mathrm{C}_{32} \mathrm{H}_{24} \mathrm{Cl}_{2} \mathrm{~N}_{2} \mathrm{O}_{2}$ & 182 & 86 & $49.57(49.48)$ & $3.12(3.11)$ & $14.41(14.43)$ \\
$\mathrm{L}_{4}$ & $\mathrm{C}_{32} \mathrm{H}_{25} \mathrm{ClN}_{2} \mathrm{O}_{4}$ & 195 & 84 & $58.86(61.74)$ & $3.42(3.83)$ & $8.97(9.39)$ \\
$\mathrm{L}_{5}$ & $\mathrm{C}_{32} \mathrm{H}_{24} \mathrm{Cl}_{2} \mathrm{~N}_{2} \mathrm{O}_{4}$ & 187 & 82 & $63.17(63.15)$ & $4.43(4.45)$ & $8.81(8.84)$ \\
$\mathrm{L}_{6}$ & $\mathrm{C}_{31} \mathrm{H}_{22} \mathrm{Cl}_{2} \mathrm{~N}_{2} \mathrm{O}_{3}$ & 183 & 82 & $56.11(56.09)$ & $3.28(3.27)$ & $11.37(11.38)$ \\
{$\left[\mathrm{Cu}\left(\mathrm{L}_{1}\right)_{2}\left(\mathrm{OH}_{2}\right)\right](\mathrm{AcO})_{2}$} & $\mathrm{C}_{68} \mathrm{H}_{62} \mathrm{~N}_{4} \mathrm{O}_{10} \mathrm{Cu}$ & $232^{*}$ & 72 & $70.53(70.48)$ & $5.42(5.39)$ & $4.87(4.83)$ \\
{$\left[\mathrm{Cu}\left(\mathrm{L}_{2}\right)_{2}\left(\mathrm{OH}_{2}\right)\right](\mathrm{AcO})_{2}$} & $\mathrm{C}_{68} \mathrm{H}_{60} \mathrm{~N}_{4} \mathrm{O}_{10} \mathrm{Cl}_{2} \mathrm{Cu}$ & $230^{*}$ & 68 & $66.83(66.53)$ & $4.91(4.93)$ & $4.58(4.56)$ \\
{$\left[\mathrm{Cu}\left(\mathrm{L}_{3}\right)_{2}\left(\mathrm{OH}_{2}\right)\right](\mathrm{AcO})_{2}$} & $\mathrm{C}_{68} \mathrm{H}_{58} \mathrm{~N}_{4} \mathrm{O}_{10} \mathrm{Cl}_{4} \mathrm{Cu}$ & $193^{*}$ & 70 & $63.18(62.99)$ & $4.49(4.51)$ & $4.33(4.32)$ \\
{$\left[\mathrm{Cu}\left(\mathrm{L}_{4}\right)_{2}\left(\mathrm{OH}_{2}\right)\right](\mathrm{AcO})_{2}$} & $\mathrm{C}_{68} \mathrm{H}_{60} \mathrm{~N}_{4} \mathrm{O}_{14} \mathrm{Cl}_{2} \mathrm{Cu}$ & $198^{*}$ & 66 & $63.38(63.23)$ & $4.70(4.68)$ & $4.36(4.34)$ \\
{$\left[\mathrm{Cu}\left(\mathrm{L}_{5}\right)_{2}\left(\mathrm{OH}_{2}\right)\right](\mathrm{AcO})_{2}$} & $\mathrm{C}_{68} \mathrm{H}_{58} \mathrm{~N}_{4} \mathrm{O}_{14} \mathrm{Cl}_{4} \mathrm{Cu}$ & $196^{*}$ & 72 & $60.42(60.03)$ & $4.27(4.30)$ & $4.14(4.12)$ \\
{$\left[\mathrm{Cu}\left(\mathrm{L}_{6}\right)_{2}\left(\mathrm{OH}_{2}\right)\right](\mathrm{AcO})_{2}$} & $\mathrm{C}_{68} \mathrm{H}_{54} \mathrm{~N}_{4} \mathrm{O}_{12} \mathrm{Cl}_{4} \mathrm{Cu}$ & $208^{*}$ & 68 & $61.09(60.95)$ & $4.22(4.19)$ & $4.28(4.31)$ \\
\hline
\end{tabular}

"Decomposition point

reaction with $\mathrm{Cu}(\mathrm{OAc})_{2} \mathrm{H}_{2} \mathrm{O}$ salt, yields complexes corresponding to the general formula $\left[\mathrm{Cu}\left(\mathrm{L}_{1-6}\right)_{2}\left(\mathrm{OH}_{2}\right)_{2}\right](\mathrm{OAc})_{2}$. The newly synthesized copper(II) complexes are very stable at room temperature in the solid state. The ligands $\left(\mathbf{L}_{\mathbf{1 - 6}}\right)$ are soluble in common organic solvents. But its metal complexes are generally soluble DMF and DMSO. The yields, melting points and elemental analyses of ligands and complexes are presented in Table 1.

We have already made numerous efforts to crystallize the complexes for X-ray diffraction studies. A single crystal of the complexes could not be isolated from any common solvent, therefore the possible structure was pre- dicted based on analytical, spectroscopic, theoretical calculations, magnetic and thermal data. While the ligands $\left(\mathbf{L}_{1-6}\right)$ melted at between $176-223{ }^{\circ} \mathrm{C}$, the copper(II) complexes melted at between $193-232{ }^{\circ} \mathrm{C}$ which are slightly above ligands melting points. The yields of the purified copper(II) complexes varied from 66 to $72 \%$. Besides, magnetic moment values of the copper(II) complexes were found in the 2.04-2.12 $\mu_{\mathrm{B}}$ range, which is very close to the spin only value of $1.73 \mu_{\mathrm{B}}$ for [Ar] $3 d^{9}$ typical value of $s=1 / 2$ copper(II). The analytical data and theoretical calculations was found to be consistent with the proposed stoichiometry of the complexes and as a consequence, the interaction between

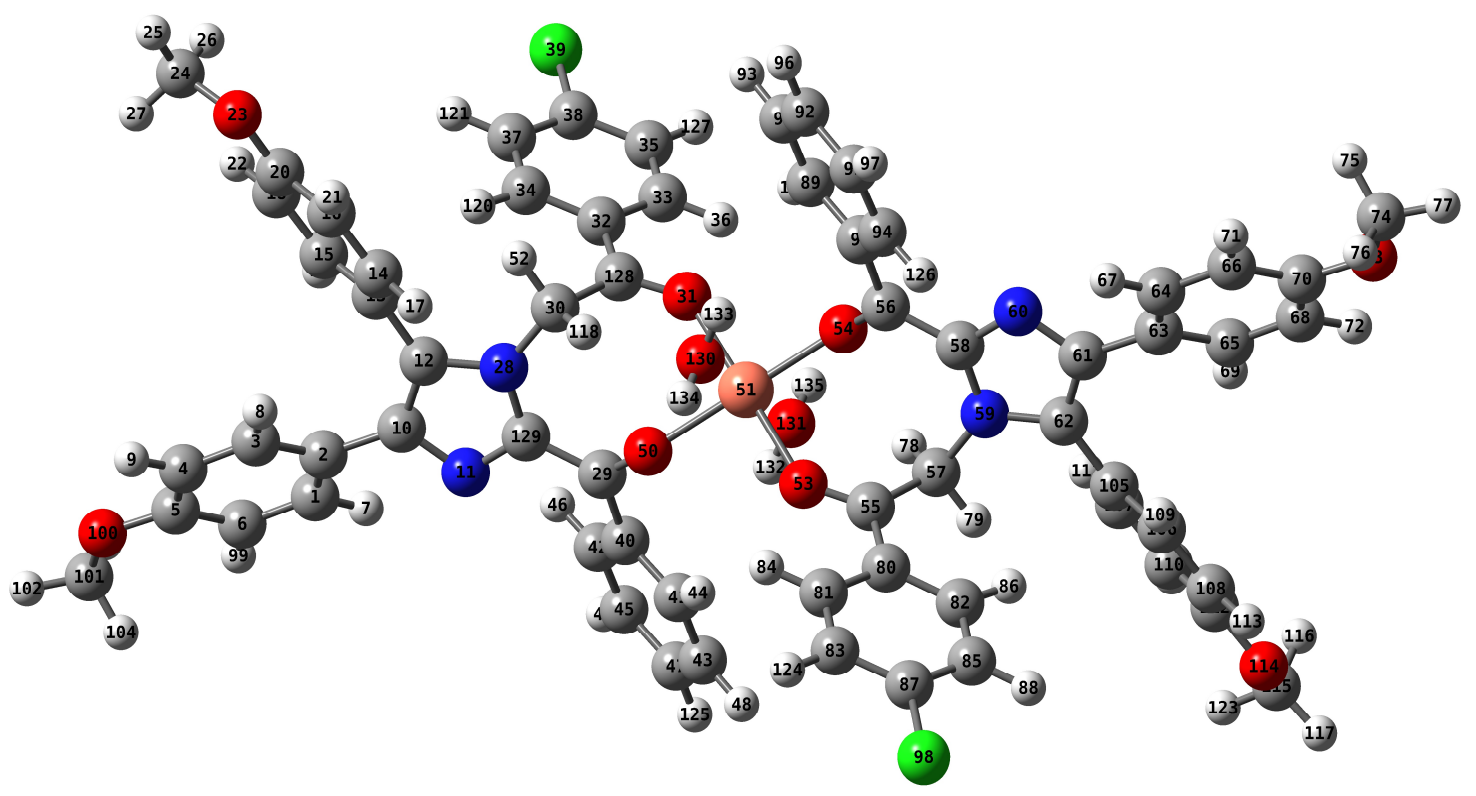

Figure 3. Assignment of numbers on proton, carbon, nitrogen, oxygen and chloride atoms of the copper(II) complex in molecular modelling, $\left[\mathrm{Cu}\left(\mathrm{L}_{4}\right)_{2}\left(\mathrm{OH}_{2}\right)\right]^{2+}$. 
Table 2. Characteristic IR bands of the ligands and their copper(II) complexes $\left(\mathrm{cm}^{-1}\right)$

\begin{tabular}{|c|c|c|c|c|c|}
\hline Ligand/Complex & $\tilde{V}(\mathrm{C}=\mathrm{O})^{(\mathrm{a})}$ & $\tilde{V}(\mathrm{C}=\mathrm{O})^{(\mathrm{b})}$ & $\tilde{v}(C=N, C=C)$ & $\tilde{v}\left(\mathrm{M}-\mathrm{OH}_{2}\right)$ & $\tilde{v}(\mathrm{M}-\mathrm{O})$ \\
\hline $\mathrm{L}_{1}$ & $1702 ; 1637$ & - & $1595-1454$ & - & \\
\hline$\left[\mathrm{Cu}\left(\mathrm{L}_{1}\right)_{2}\left(\mathrm{OH}_{2}\right)\right](\mathrm{AcO})_{2}$ & $1700 ; 1635$ & 1442 & $1598-1457$ & $716 / 3268$ & 476 \\
\hline $\mathrm{L}_{2}$ & $1700 ; 1622$ & & $1588-1452$ & - & \\
\hline$\left[\mathrm{Cu}\left(\mathrm{L}_{2}\right)_{2}\left(\mathrm{OH}_{2}\right)\right](\mathrm{AcO})_{2}$ & $1695 ; 1636$ & 1440 & $1589-1457$ & $746 / 3470$ & 474 \\
\hline $\mathrm{L}_{3}$ & $1698 ; 1635$ & & $1587-1449$ & - & \\
\hline$\left[\mathrm{Cu}\left(\mathrm{L}_{3}\right)_{2}\left(\mathrm{OH}_{2}\right)\right](\mathrm{AcO})_{2}$ & $1617 ; 1586$ & 1446 & $1572-1490$ & $734 / 3368$ & 476 \\
\hline $\mathrm{L}_{4}$ & 1699; 1619 & & $1585-1449$ & - & \\
\hline$\left[\mathrm{Cu}\left(\mathrm{L}_{4}\right)_{2}\left(\mathrm{OH}_{2}\right)\right](\mathrm{AcO})_{2}$ & $1700 ; 1615$ & 1444 & $1583-1457$ & $730 / 3462$ & 478 \\
\hline $\mathrm{L}_{5}$ & $1698 ; 1617$ & & $1588-1448$ & - & \\
\hline$\left[\mathrm{Cu}\left(\mathrm{L}_{5}\right)_{2}\left(\mathrm{OH}_{2}\right)\right](\mathrm{AcO})_{2}$ & $1699 ; 1615$ & 1448 & $1587-1449$ & $764 / 3480$ & 476 \\
\hline $\mathrm{L}_{6}$ & $1697 ; 1639$ & & $1600-1453$ & - & \\
\hline$\left[\mathrm{Cu}\left(\mathrm{L}_{6}\right)_{2}\left(\mathrm{OH}_{2}\right)\right](\mathrm{AcO})_{2}$ & $1686 ; 1635$ & 1454 & 1599-1457 & $687 / 3474$ & 478 \\
\hline
\end{tabular}

(a) carbonyl groups as a functional group; (b) carbonyl group at acetate anion

copper(II) ions with ligands to form mononuclear, hexacoordinated copper(II) complexes as shown in Figures 2 and 3.

\section{Infrared Spectroscopy}

Table 2 presents the most important IR spectral bands for the ligands containing dissymmetrical carbonyl groups and their copper(II) complexes. The bands at $1615-1702 \mathrm{~cm}^{-1}$ were assigned to the $(\mathrm{C}=0)$ groups in all the complexes and ligands. These bands are shifted in the complexes toward lower frequencies because of the coordination of the donor oxygen atoms of the carbonyl groups to metal atom and resulting weakening of the $(\mathrm{C}=0)$ bond. ${ }^{[25,26]}$ This feature can be explained by transfer of electrons from the oxygen atom to metal atom due to coordination.

The infrared spectra of the complexes exhibited broad bands at $3200-3500 \mathrm{~cm}^{-1}$ that are attributed to $\mathrm{OH}$ group of the coordinated water. ${ }^{[27]}$ The presence of coordinated water was further confirmed by the apperance of a non-ligand band in the region $687-764 \mathrm{~cm}^{-1}$, assignable to the wagging mode of water ${ }^{[27,28]}$ which support the presence of coordinated water. This coordination was also established and supported by TG and DTA analyses. In the low frequency region, spectra of the copper complexes exhibit new band which are not present in spectra of the ligand. These bands at $474-478 \mathrm{~cm}^{-1}$ region observed in all complexes could be tentatively assigned to $\tilde{v}(\mathrm{M}-\mathrm{O})$ vibrations. ${ }^{[24,29,30]}$ In the other band, acetate anion bands for complexes were observed at $1440-1454 \mathrm{~cm}^{-1}$ which indicated to the mentioned anion. ${ }^{[31]}$

\section{Magnetic and Electronic Absorption Spectroscopy}

The electronic absorption spectra of the ligands are characterized by two intense absorption bands. Two bands appeared at $249-276 \mathrm{~nm}$ and $348-377 \mathrm{~nm}$, which can be assigned to $\pi \rightarrow \pi^{*}$ and $n \rightarrow \pi^{*}$ transitions, respectively, in all the ligands (Table 3). ${ }^{[32,33]}$

The comparison of electronic spectra of the free ligands and copper(II) complexes in DMF solvent produce

Table 3. UV-VIS dates for the ligands and their copper(II) complexes in DMF and magnetic moment values

\begin{tabular}{llc}
\hline Ligand/Complex & $\lambda_{\max } / \mathrm{nm}$ & $\mu_{\text {eff }} /$ B.M. \\
\hline $\mathrm{L}_{1}$ & 249,360 & - \\
{$\left[\mathrm{Cu}\left(\mathrm{L}_{1}\right)_{2}\left(\mathrm{OH}_{2}\right)\right](\mathrm{AcO})_{2}$} & $249,365,438^{*}, 634$ & 2.04 \\
$\mathrm{~L}_{2}$ & 259,361, & - \\
{$\left[\mathrm{Cu}\left(\mathrm{L}_{2}\right)_{2}\left(\mathrm{OH}_{2}\right)\right](\mathrm{AcO})_{2}$} & $249,370,444^{*}, 654$ & 2.04 \\
$\mathrm{~L}_{3}$ & 260,367 & - \\
{$\left[\mathrm{Cu}\left(\mathrm{L}_{3}\right)_{2}\left(\mathrm{OH}_{2}\right)\right](\mathrm{AcO})_{2}$} & $249,377,445^{*}, 648$ & 2.06 \\
$\mathrm{~L}_{4}$ & 259,370 & - \\
{$\left[\mathrm{Cu}\left(\mathrm{L}_{4}\right)_{2}\left(\mathrm{OH}_{2}\right)\right](\mathrm{AcO})_{2}$} & $252,379,474^{*}, 660$ & 2.12 \\
$\mathrm{~L}_{5}$ & 260,377 & - \\
{$\left[\mathrm{Cu}\left(\mathrm{L}_{5}\right)_{2}\left(\mathrm{OH}_{2}\right)\right](\mathrm{AcO})_{2}$} & $249,382,460^{*}, 642$ & 2.08 \\
$\mathrm{~L} 6$ & 276,348 & - \\
{$\left[\mathrm{Cu}\left(\mathrm{L}_{6}\right)_{2}\left(\mathrm{OH}_{2}\right)\right](\mathrm{AcO})_{2}$} & $278,349,433^{*}, 635$ & 2.12 \\
\hline shoulder & &
\end{tabular}


Table 4. Photoluminescent $\lambda_{\max }$ values of copper(II) complexes at $355 \mathrm{~nm}$ excitation

\begin{tabular}{ll}
\hline Compound & Emission $/ \mathrm{nm}$ \\
\hline$\left[\mathrm{Cu}\left(L_{1}\right)_{2}\left(\mathrm{OH}_{2}\right)\right](\mathrm{ACO})_{2}$ & 512 \\
{$\left[\mathrm{Cu}\left(L_{2}\right)_{2}\left(\mathrm{OH}_{2}\right)\right](\mathrm{ACO})_{2}$} & 508 \\
{$\left[\mathrm{Cu}\left(L_{3}\right)_{2}\left(\mathrm{OH}_{2}\right)\right](\mathrm{ACO})_{2}$} & 484 \\
{$\left[\mathrm{Cu}\left(\mathrm{L}_{4}\right)_{2}\left(\mathrm{OH}_{2}\right)\right](\mathrm{AcO})_{2}$} & 497 \\
{$\left[\mathrm{Cu}\left(L_{5}\right)_{2}\left(\mathrm{OH}_{2}\right)\right](\mathrm{AcO})_{2}$} & 527 \\
{$\left[\mathrm{Cu}\left(L_{6}\right)_{2}\left(\mathrm{OH}_{2}\right)\right](\mathrm{AcO})_{2}$} & 479 \\
\hline
\end{tabular}

additional strong evidence for the sharing of carbonyl groups in complexation process. This evidence is based on the red shift of the free ligands bands to lower frequencies in the spectra of their copper complexes. The electronic spectra of the complexes showed two low-energy bands at 634-660 $\mathrm{nm}$ and strong high-energy at $433-474 \mathrm{~nm}$. The low-energy band in the position typically is expected for an octahedral distorted configuration and may be associated with $d$ - $d$ transitions assignable to ${ }^{2} \mathrm{E}_{\mathrm{g}} \rightarrow{ }^{2} \mathrm{~T}_{2 \mathrm{~g}}$. The strong high-energy band is assigned to metal-ligand charge transfer. The obtained values of the effective magnetic moment for the complexes (2.04-2.12 $\left.\mu_{\mathrm{B}}\right)$ are typical for distorted octahedral copper(II) complexes. ${ }^{[34-36]}$

\section{Photoluminescent Properties}

The fluorescence efficiency of the ligands and their copper(II) complexes were explored at room temperature in DMF solution. The ligands exhibit the photoluminescence with emission at 471-499 $\mathrm{nm}$ upon excitation at $355 \mathrm{~nm}$. However, the copper(II) complexes give an intense broad emission band at 479-527 $\mathrm{nm}$ with high quantum yield upon excitation at $355 \mathrm{~nm}$ (Table 4). The emission intensity observed in the complexes is assigned to intra-ligand $\left(\pi \rightarrow \pi^{*}\right)$ fluorescence and these are red shifted. The enhanced fluorescence efficiency of the complexes is

Table 5. Thermal decomposition of the ligands and their copper(II) complexes

\begin{tabular}{|c|c|c|c|c|}
\hline Compounds & Stage & $\begin{array}{l}\text { Mass loss } \\
\text { temp. } /{ }^{\circ} \mathrm{C}\end{array}$ & $\begin{array}{l}\text { Max. mass } \\
\text { loss / \% }\end{array}$ & $\mathrm{DTA}_{\max } /{ }^{\circ} \mathrm{C}$ \\
\hline \multirow[t]{3}{*}{$\mathrm{L}_{1}$} & 1 & $374-464$ & 48 & 396 endo \\
\hline & 2 & $472-654$ & 37 & 571 endo \\
\hline & 3 & $658-818$ & 15 & 742 endo \\
\hline \multirow[t]{3}{*}[\mathrm{Cu}(\mathrm{L}_{1})_{2}(\mathrm{OH}_{2})]{$(\mathrm{AcO})_{2}$} & 1 & $232-345$ & 14 & 302 endo \\
\hline & 2 & $348-560$ & 51 & 432 endo \\
\hline & 3 & $561-906$ & 29 & 762 endo \\
\hline \multirow[t]{3}{*}{$\mathrm{L}_{2}$} & 1 & $372-460$ & 47 & 412 endo \\
\hline & 2 & $465-652$ & 39 & 568 endo \\
\hline & 3 & $654-816$ & 14 & 746 endo \\
\hline \multirow[t]{3}{*}[\mathrm{Cu}(\mathrm{L}_{2})_{2}(\mathrm{OH}_{2})]{$(\mathrm{AcO})_{2}$} & 1 & $231-348$ & 13 & 304 endo \\
\hline & 2 & $350-576$ & 48 & 428 endo \\
\hline & 3 & $580-912$ & 34 & 734 endo \\
\hline \multirow[t]{3}{*}{$\mathrm{L}_{3}$} & 1 & $368-462$ & 48 & 398 endo \\
\hline & 2 & $464-658$ & 40 & 575 endo \\
\hline & 3 & $662-798$ & 12 & 738 endo \\
\hline \multirow[t]{3}{*}[\mathrm{Cu}(\mathrm{L}_{3})_{2}(\mathrm{OH}_{2})]{$(\mathrm{AcO})_{2}$} & 1 & $195-334$ & 15 & 297 endo \\
\hline & 2 & $338-642$ & 48 & 420 endo \\
\hline & 3 & $644-886$ & 32 & 718 endo \\
\hline \multirow[t]{3}{*}{$\mathrm{L}_{4}$} & 1 & $362-468$ & 52 & 398 endo \\
\hline & 2 & $474-640$ & 36 & 624 endo \\
\hline & 3 & $642-826$ & 12 & 758 endo \\
\hline \multirow[t]{3}{*}[\mathrm{Cu}(\mathrm{L}_{4})_{2}(\mathrm{OH}_{2})]{$(\mathrm{AcO})_{2}$} & 1 & $198-324$ & 12 & 298 endo \\
\hline & 2 & $326-552$ & 49 & 416 endo \\
\hline & 3 & $554-918$ & 33 & 786 endo \\
\hline \multirow[t]{3}{*}{$\mathrm{L}_{5}$} & 1 & $358-462$ & 53 & 396 endo \\
\hline & 2 & $465-634$ & 36 & 614 endo \\
\hline & 3 & $638-827$ & 11 & 748 endo \\
\hline \multirow[t]{3}{*}[\mathrm{Cu}(\mathrm{L}_{5})_{2}(\mathrm{OH}_{2})]{$(\mathrm{AcO})_{2}$} & 1 & $196-332$ & 13 & 286 endo \\
\hline & 2 & $333-552$ & 49 & 416 endo \\
\hline & 3 & 554-902 & 32 & 782 endo \\
\hline \multirow[t]{3}{*}{$\mathrm{L}_{6}$} & 1 & $368-466$ & 50 & 402 endo \\
\hline & 2 & $468-652$ & 37 & 612 endo \\
\hline & 3 & $656-828$ & 13 & 744 endo \\
\hline \multirow[t]{3}{*}[\mathrm{Cu}(\mathrm{L}_{6})_{2}(\mathrm{OH}_{2})]{$(\mathrm{AcO})_{2}$} & 1 & $210-358$ & 14 & 288 endo \\
\hline & 2 & $360-596$ & 50 & 432 endo \\
\hline & 3 & 598-912 & 31 & 776 endo \\
\hline
\end{tabular}


attributed to the coordination of the ligands to the copper(II) ions which effectively increases the rigidity of the ligands and reduces the loss of energy via radiation less thermal vibrational decay. ${ }^{[37]}$

\section{TG/DTA Analyses}

The obtained thermoanalytical results from TG and DTA curves for ligands and complexes are given in Table 5. The data from the thermogravimetric analyses indicated that the decomposition of the complexes and the ligands proceeds in three steps. Thermal stability of complexes exhibits the similar trend in ligands.

The comparison of ligands and the complexes shows that the complexes were more thermally stable at average $19{ }^{\circ} \mathrm{C}$ higher than that of the ligands. The first stage for all studied complexes is the loss of adsorbed water at $86-107^{\circ} \mathrm{C}$, followed in a second decomposition stage by the loss of the coordinated water, acetate ions at the range $195-358^{\circ} \mathrm{C},[38]$ after that, the decomposition was complete at the range $886-918{ }^{\circ} \mathrm{C}$ for all complexes. As expected, in the copper(II) complexes, the endothermic peak belong to about $198^{\circ} \mathrm{C}$ the first weight loss corresponding to the removal of coordinated $\mathrm{H}_{2} \mathrm{O}$ is $\approx 3.0 \%$. Subsequently, similarly decomposition steps of the ligands, the decomposition in the complexes was found to occur the three stages. At the end of thermal decomposition process of the ligands were not found any residue, but the residue at the end of the last step of the decomposition of the complexes was observed to be about $5.0 \%$ and it can be attributed to the metal oxide and nitrid residue thus indicating the presence of the metal in the sample.

\section{Theoretical Calculations}

Gaussian approximates orbital shapes and orbital energies of a given molecular geometry using a model chemistry consisting of two parts: a basis set and a method. Calculations using large basis sets are more accurate because they are less restrictive on the location of the electrons. Such calculations are also more expensive because they require computing more integrals. DFT methods account for electron correlation by estimating the interaction of an electron with the total electron density. DFT orbitals are formed from basis functions like those used in SCF or MP2. Most popular DFT method is B3LYP (Becke3-Parameter method for calculating that part of the molecular energy due to overlapping orbitals, plus the Lee-Yang-Parr method of accounting for correlation) $)^{20-23}$. The optimized geometric parameters (bond lengths and dihedral angles), conformational analysis, normal mode frequencies and corresponding vibrational assignments of copper(II) complex, $\left[\mathrm{Cu}\left(\mathrm{L}_{4}\right)_{2}\left(\mathrm{OH}_{2}\right)_{2}\right]^{2+}$ are theoretically examined by means of B3LYP hybrid DFT and HF methods in 6-31G(d) basis set level.

In order to study the correlation of the calculated infrared spectra for the copper(II) complex of ligand $L_{4}, 8$ data for its are used as given Table 8. The calculated thermodynamic

parameters, assignment of numbers on proton, carbon, nitrogen, oxygen and chloride atoms of the copper(II) complex, $\left[\mathrm{Cu}\left(\mathrm{L}_{4}\right)_{2}\left(\mathrm{OH}_{2}\right)\right]^{2+}$ in molecular modelling, bonds lengths and angles are given in Table 6, 7 and Figure 3, respectively.

The performance of the B3LYP/6-31G(d) and HF/6$31 \mathrm{G}(\mathrm{d})$ methods used to predict the relative shielding within the molecule were close to each other. Although two methods have close to values, the results of the vibrational spectra data predicted from $\mathrm{HF} / 6-31 \mathrm{G}(\mathrm{d})$ are more correlated with the experiment than those of B $3 \mathrm{LYP} / 6-31 \mathrm{G}(\mathrm{d})$ as shown in Table 8.

The minimum energy of geometrical structure was obtained by using level 6-31G(d) basis set. The vibrational wavenumbers were calculated and the complete assignments for $\mathrm{C}=\mathrm{O}$ and $\mathrm{Cu}-\mathrm{O}$. The selected some vibration values in the calculated wavenumbers were compared with experimental FT-IR spectra as shown in Table 8. The calculated vibration frequencies were showed in good agreement with experiment values for these compounds.

As shown in the Figure 2 and 3, there is a distorted octahedral geometry of the copper(II) complex,

Table 6. The calculated some parameters of copper(II) complex, $\left[\mathrm{Cu}\left(\mathrm{L}_{4}\right)_{2}\left(\mathrm{OH}_{2}\right)\right]^{2+}$

\begin{tabular}{lll}
\hline Parameters & HF/6-31G(d) & B3LYP/6-31G(d) \\
\hline$E\left(\right.$ Thermal) $\left(\mathrm{kcal} \mathrm{mol}^{-1}\right)$ & 745.707 & 708.643 \\
Sum of electronic and zero-point Energies (a.u.) & -5977.686938 & -6001.817560 \\
Zero point vib. energy (kcal mol-1) & 699.14741 & 660.53299 \\
Specific heat (Cv) (cal mol $\left.{ }^{-1} \mathrm{~K}^{-1}\right)$ & 276.827 & 289.094 \\
Entropy (S) (cal mol $\left.\mathrm{K}^{-1}\right)$ & 422.833 & 431.004 \\
Dipole moment & 2.5034 & 2.6925 \\
Rotational constants (GHz) & 0.03255 & 0.03279 \\
& 0.01101 & 0.01117 \\
\hline
\end{tabular}

DOI: $10.5562 /$ cca2820 
Table 7. The calculated bond lengths and angles (angstroms and degrees) for copper(II) complex, $\left.\left[\mathrm{Cu}_{(\mathrm{L}}\right)_{2}\left(\mathrm{OH}_{2}\right)\right]^{2+}$

\begin{tabular}{|c|c|c|c|c|c|}
\hline \multicolumn{4}{|c|}{ Bond lengths / $\AA$} & \multicolumn{2}{|c|}{ Bond angles $/^{\circ}$} \\
\hline Definition & $\mathrm{HF} / 6-31 \mathrm{G}(\mathrm{d})$ & B3LYP/6-31G(d) & Definition & $\mathrm{HF} / 6-31 \mathrm{G}(\mathrm{d})$ & B3LYP/6-31G(d) \\
\hline$R(51,31)$ & 2.0605 & 1.9940 & $A(31,51,50)$ & 84.9011 & 87.9742 \\
\hline$R(51,50)$ & 1.9945 & 1.9375 & $A(31,51,54)$ & 94.7603 & 92.2920 \\
\hline$R(51,53)$ & 2.0560 & 2.0121 & $A(31,51,130)$ & 93.1486 & 99.8972 \\
\hline$R(51,54)$ & 1.9776 & 1.9259 & $A(31,51,131)$ & 87.7851 & 87.0576 \\
\hline$R(51,130)$ & 2.3151 & 2.3674 & $A(50,51,53)$ & 94.2748 & 91.5283 \\
\hline \multirow[t]{7}{*}{$R(51,131)$} & 2.3119 & 2.3657 & $A(50,51,130)$ & 89.9017 & 82.6151 \\
\hline & & & $A(50,51,131)$ & 89.3761 & 93.0836 \\
\hline & & & $A(53,51,54)$ & 86.7666 & 88.3984 \\
\hline & & & $A(53,51,130)$ & 86.7666 & 83.7248 \\
\hline & & & $A(53,51,131)$ & 92.2881 & 89.2525 \\
\hline & & & $A(54,51,130)$ & 90.8851 & 94.4135 \\
\hline & & & $A(54,51,131)$ & 89.8425 & 89.8974 \\
\hline
\end{tabular}

Table 8. Values of the infrared spectral bands $\left(\mathrm{cm}^{-1}\right)$ for the copper(II) complex, $\left[\mathrm{Cu}\left(\mathrm{L}_{4}\right)_{2}\left(\mathrm{OH}_{2}\right)\right]^{2+}$, as computed using B3LYP/6$31 \mathrm{G}(\mathrm{d})$ and $\mathrm{HF}$ methods, and available experimental data

\begin{tabular}{cccc}
\hline Numbers of atom & Exp. $\left(\mathrm{cm}^{-1}\right)$ & B3LYP $\left(\mathrm{cm}^{-1}\right)$ & $\mathrm{HF}\left(\mathrm{cm}^{-1}\right)$ \\
\hline $\mathrm{O}_{53}-\mathrm{C}_{55}$ & 1615 & $1645(v)$ & $1625(v)$ \\
$\mathrm{O}_{54}-\mathrm{C}_{56}$ & 1700 & $1662(v)$ & $1727(v)$ \\
$\mathrm{O}_{53}-\mathrm{Cu}+\mathrm{O}_{31} \mathrm{Cu}+\mathrm{O}_{54}-\mathrm{Cu}+\mathrm{O}_{50}-\mathrm{Cu}$ & 478 & $570(v)$ & $568\left(v_{\text {ass }}\right)$ \\
$\mathrm{O}_{130}-\mathrm{Cu}+\mathrm{O}_{131}-\mathrm{Cu}$ & $730 / 3462$ & $763(\tau) / 3560(v)$ & $752(\tau) / 3546(v)$ \\
\hline
\end{tabular}

$v$ : stretching; $\tau$ : torsion.

$\left[\mathrm{Cu}\left(\mathrm{L}_{4}\right)_{2}\left(\mathrm{OH}_{2}\right)\right]^{2+}$ between the theoretical and experimental results.

\section{CONCLUSIONS}

We have prepared a series of copper(II) complexes, $\left[\mathrm{Cu}\left(\mathrm{L}_{1-6}\right)_{2}\right.$ $\left.\left(\mathrm{OH}_{2}\right)_{2}\right](\mathrm{OAc})_{2}$ based on 1,2,4,5-tetrasubstituted imidazole derivatives containing dissymmetrical carbonyl groups $\left(\mathbf{L}_{\mathbf{1}}\right.$ 6) and characterized by elemental analysis, spectroscopic methods, MALDI-TOF MS data, magnetic measurements and TG-DTA analysis, thin-layer chromatography. The $\mathrm{M}^{+}$ and $\mathrm{M}^{2+}$ peaks in MS spectra of copper(II) complexes and their elemental analyses were detected to have 1:2 metal/ligand ratio and containing two number coordinated water. This coordination was also established and supported by TG and DTA analyses. The data from the thermogravimetric analyses shows that the decomposition of the complexes and the ligands proceeds in three steps. Thermal stability of complexes exhibits the similar trend in ligands.
The infrared, UV-Vis, elemental analyses, and magnetic studies suggest that the oxygen atom on carbonyl groups of the ligand and coordinated water oxygen atom are coordinated and covalently bonded, respectively, to metal atoms. The ligand thus behaves as bidentate. In this study, there was also presented the calculated vibrations with B3LYP and HF methods in 6-31G(d) base set and were compared with experimental results. The calculated vibrations were found to be close to the experimental values for the copper(II) complex, $\left[\mathrm{Cu}\left(\mathrm{L}_{4}\right)_{2}\left(\mathrm{OH}_{2}\right)\right]^{2+}$, moreover its bond lengths and dihedral angles in distorted octahedral geometry were calculated as theoretical with B3LYP and HF methods in $6-31 \mathrm{G}(\mathrm{d})$ base set. On the other hand, the fluorescence property of copper(II) complexes was studied and it was found that all the copper(II) complexes exhibit intraligand $\left(\pi \rightarrow \pi^{*}\right)$ fluorescence in blue-green region with high quantum yield in DMF solution. The observation of complex formation with selectively only copper ion in the $\mathrm{Cr}^{3+}, \mathrm{Co}^{2+}, \mathrm{Ni}^{2+}, \mathrm{Cu}^{2+}$ and $\mathrm{Zn}^{2+}$ ions, due to suitability of the steric effect and the size of ligand molecule and the 
charge/radius of metal ion can be related to stable structure. Therefore, these ligands having 1,2,4,5-tetrasubstituted imidazole moiety has selective property for $\mathrm{Cu}^{2+}$ ion. We believe that these observations regarding the interaction and $\mathrm{Cu}^{2+}$ ions should serve as the basis for new strategies to design new chemosensors based on 1,2,4,5tetrasubstituted imidazoles even although copper ion recognition by other systems has been described. In particularly, these ligands can be used as a new practical reagent for analytical applications.

Acknowledgment. The authors are grateful to PAUBAP (Project No: 2012BSP004) and TUBITAK (Project No: 107T606) for financial support the project number. Computation has been performed using TUBITAK/ULAKBIM clusters.

\section{REFERENCES}

[1] B. Valeur, I. Leray, Coord. Chem. Rev. 2000, 205, 3.

[2] T. Gabe, Y. Urano, K. Kikuchi, H. Kojima, T. Nagano, J. Am. Chem. Soc. 2004, 126, 3357.

[3] S. L. Wiskur, S. Ait-Haddou, J. J. Lavigne, E. V. Anslyn, Acc. Chem. Res. 2001, 34, 963.

[4] E.L. Que, D.W. Domaille, C. Chang, J. Chem. Rev. 2008, 108, 1517.

[5] B. Sarkar, Transport of copper in metal ions in biological systems, in Metal ions in biological systems, Vol. 12 (Eds.: H. Siegel, A. Siegel, M. Dekker), New York, 1981, pp 233-281.

[6] R. A. Lovstad, Biometals, 2004, 17, 111.

[7] H. Freitas, M. N. V. Prasad, J. Pratas, Environ. Int. 2004, 30, 65.

[8] F. M. Raymo, Adv. Mater. 2002, 14, 401.

[9] D. J. Faulkner, Nat. Prod. Rep. 2000, 17, 7.

[10] J. Z. Ho, R. M. Mohareb, J. H. Ahn, T. B. Sim, H. Ropoport, J. Org. Chem. 2003, 68, 109.

[11] M. R. Grimmett, Imidazoles, in Comprehensive Heterocyclic Chemistry II, Vol. 3 (Eds.: A. R. Katritsky, E. F. V. Scriven), Pergamon, Oxford, 1996, pp. 77220.

[12] S. H. Xiao, T. Yi, F. Y. Li, C. H. Huang, Tetrahedron Lett. 2005, 46, 9009.

[13] A. Fernandez-Acebes, J. M. Lehn, Chem. Eur. J. 1999, 5, 3285 .

[14] K. Yagi, C. F. Soong, M. Irie, J Org. Chem. 2001, 66, 5419.

[15] J. G. Lambardi, E. H. Wiseman, J. Med. Chem. 1974, 17, 1182.

[16] M. Doble, A. Puratchikody, Bioorg. Med. Chem. 2007, 15, 1083.

[17] Ş. Demirayak, I. Kayagil, J. Heterocycl. Chem., 2005, 42, 319.

[18] I. Kayagil, Ş. Demirayak, Turk. J. Chem. 2011, 35, 13.
[19] A. Earnshaw, Introduction to magnetochemistry, Academic Press., London, 1968, p. 4.

[20] J. B. Foresman, A. E. Frisch, Exploring chemistry with electronic structure methods, Gaussian Inc., (1996).

[21] D. Avcl, Theoretical investigation of some aromatic molecules containing hetero atoms, nonlinear optical and spectroscopic properties, Sakarya University, Institute of Science, PhD thesis, 2009.

[22] M. J. Frisch, G. W. Trucks, H. B. Schlegel, G. E. Scuseria, M. A. Robb, J. R. Cheeseman, G. Scalmani, V. Barone, B. Mennucci, G. A. Petersson, H. Nakatsuji, M. Caricato, X. Li, H. P. Hratchian, A. F. Izmaylov, J. Bloino, G. Zheng, J. L. Sonnenberg, M. Hada, M. Ehara, K. Toyota, R. Fukuda, J. Hasegawa, M. Ishida, T. Nakajima, Y. Honda, O. Kitao, H. Nakai, T. Vreven, J. A. Montgomery Jr, J. E. Peralta, F. Ogliaro, M. Bearpark, J. J. Heyd, E. Brothers, K. N. Kudin, V. N. Staroverov, R. Kobayashi, J. Normand, K. Raghavachari, A. Rendell, J. C. Burant, S. S. Iyengar, J. Tomasi, M. Cossi, N. Rega, J. M. Millam, M. Klene, J. E. Knox, J. B. Cross, V. Bakken, C. Adamo, J. Jaramillo, R. Gomperts, R. E. Stratmann, O. Yazyev, A. J. Austin, R. Cammi, C. Pomelli, J. W. Ochterski, R. L. Martin, K. Morokuma, V. G. Zakrzewski, G. A. Voth, P. Salvador, J. J. Dannenberg, S. Dapprich, A. D. Daniels, Ö. Farkas, J. B. Foresman, J. V. Ortiz, J. Cioslowski, D. J. Fox, Gaussian 09, Gaussian, Inc., Wallingford CT, (2009).

[23] I. Kara, H. H. Kart, N. Kolsuz, O. O. Karakus, H. Deligöz, Struct. Chem. 2009, 20, 113.

[24] M. Sonmez, A. Levent, M. Sekerci, Russ. J. Coord. Chem. 2004, 30, 655.

[25] D. A. Condit, S. M. Craven, J. E. Katon, Appl. Spectrosc. 1974, 28, 420.

[26] A. Langseth, R.C. Lord, Kgl. Danske Videnskap, Matfys Medd. 1938, 16, 85.

[27] K. Nakamoto, Infrared Spectra of Inorganic and Coordination Compounds, Wiley, $2^{\text {nd }}$ Ed., New York, 1970.

[28] I. Nakagawa, T. Shimanouchi, Spectrochim. Acta, 1964, 20, 429.

[29] M. P. Teotia, D. K. Rastogi, W. U. Malik, Inorg. Chim. Acta 1973, 7, 339.

[30] L. J. Bellamy, The Infrared Spectra of Complex Molecules, Chapmann and Hall, London, 1973.

[31] V. M. Parikh, Absorption spectroscopy of Organic molecules, Addison-Wesley Publishing Co. Inc, 1974.

[32] G. L. Almajan, S. L. Barbuceanu, I. Saramet, B. Draghici, Rev. Chim. (Bucuresti) 2007, 58, 202.

[33] E. Erdem, E. Yıldııım Sarı, R. Kılıncarslan, N. Kabay, Trans. Met. Chem. 2009, 34, 167.

[34] E. P. Powell, N. Sheppard, Spectrochim. Acta, 1961, $17,68$.

[35] E. P. Powell, N. Sheppard, J. Chem. Soc. 1961, 1112. 
[36] B. N. Figgis, Introduction to Ligand Fields, Interscience, London, 1966.

[37] B. A. Yamgar, V. A. Sawant, A. N. Jadhav, S. S.
Chavan, Inorg. Chem. Commun. 2010, 13, 1207.

[38] T. A. Yousef, G. M. Abu El-Reash, O. A. El-Gammal, R. A. Bedier, J. Mol. Struct. 2012, 1029, 149. 